\title{
PANORAMIC INDICATORS OF NEPALESE AGRICULTURE
}

\author{
Dilliram Bhattarai
}

\section{INTRODUCTION}

Nepal is purely an agrarian country with 80 percent of the total labour force engaged in agriculture sector. Out of the total land area of 2597.4 thousand hectors, agricultural land occupies 2392.9 thousand hectares, and the rest 204.5 thousand hectors of land is non-agricultural land. Of the total arable land 55 percent lies in the Terai 37.5 percent in the Hills and 7.0 percent in the mountains. At present agriculture is contributing 42 percent on the national income, and out of the country's total export 40 percent consists of agricultural products. More over it supplies raw materials to agro-based industries. The major industries in Nepal are agro-based which solely depend on agriculture for the raw materials.

Like other developing countries of the world, Nepal has to depend on agriculture for earning the hard currency required for importing capital goods from abroad. Thus, the pace of economic development depends, to a considerable extent, on exportable surplus of agricultural products.

Agricultural sectors, though very crucial in Nepalese economy, is still lagging far behind in terms of productivity and even in total production to cope with the increasing imports. Thus, it has not yet been able to increase the income level of ordinary people to fulfil the increasing basic human needs. The present paper, keeping these things in view, tries to search the panoramic indicators which account for the unsustainability in Nepalese agriculture. Agriculture in itself is a vast sector, hence, the authors gives the main emphasis on cash and cereal crops only. He does so because these crops are the major crops in Nepalese agriculture system.

\section{PANORAMIC INDICATORS}

\section{AGRICULTURAL PRODUCTIVITY}

Today, the biggest challenge for Nepalese agriculture system is to achieve agricultural productivity as the agricultural productivity has been declining year after year. Several factors are multiplying problem in Nepal. National sample census of agriculture 1991 reveals that 69.4 percent land holders have less than one hectare of land. In other words, 69.4 percent of the total land holders have poor economic condition. The poor economic condition of the Nepalese peasants has not restricted the agricultural productivity but also hampered the use of better modern technology. Hence, to raise the productivity and to use the farm worker more effectively is a major problem. 
Table-1 Area, Production and Productivity of Major crops 1986/87 and 96/97.

Area:

In thousand hectares

Plond.

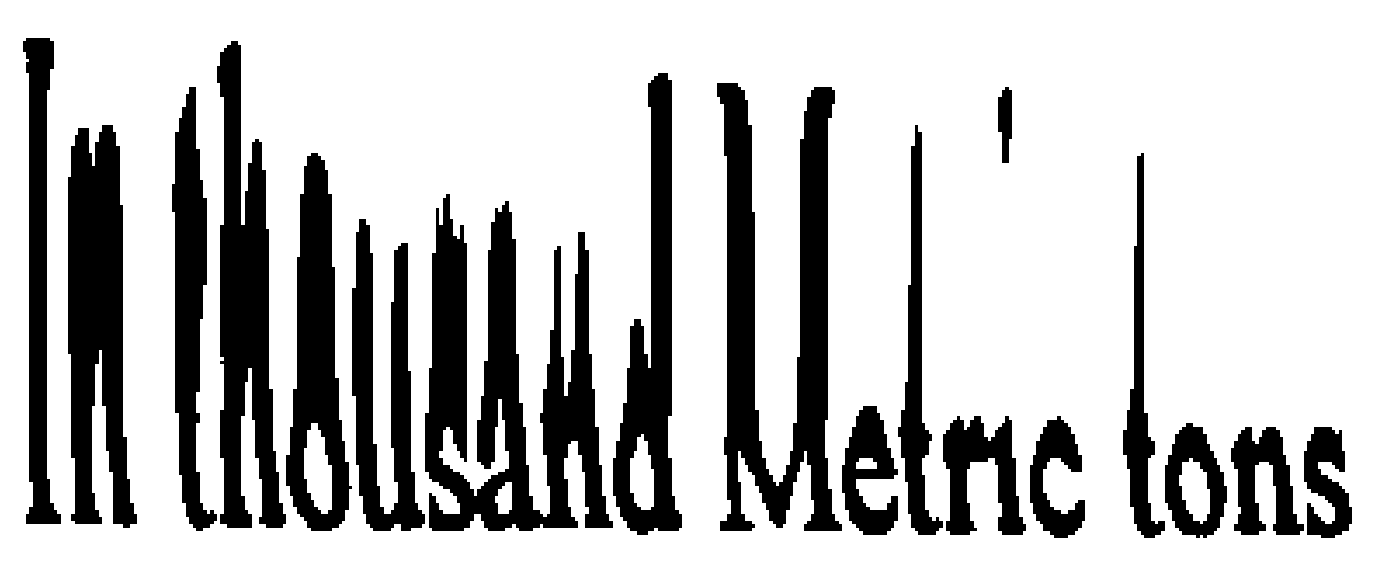

Productivity: Metric tons/hectors.

\begin{tabular}{|l|l|r|r|r|r|r|r|r|r|c|}
\hline & Year & Paddy & Wheat & Maize & Millet & $\begin{array}{l}\text { Bar- } \\
\text { ley }\end{array}$ & $\begin{array}{l}\text { Oil- } \\
\text { seed }\end{array}$ & Potato & $\begin{array}{l}\text { Tobac } \\
\text {-co }\end{array}$ & $\begin{array}{l}\text { Sugar } \\
\text { cane }\end{array}$ \\
\hline Area & $86 / 87$ & 1333 & 535 & 627 & 151 & 28 & 142 & 74 & 8 & 24 \\
\hline & $96 / 97$ & 1511 & 667 & 793 & 259 & 35 & 182 & 110 & 5 & 46 \\
\hline prod $^{\text {on }}$ & $86 / 87$ & 2372 & 701 & 868 & 137 & 25 & 82 & 395 & 5 & 616 \\
\hline & $96 / 97$ & 3710 & 1071 & 132 & 289 & 37 & 119 & 997 & 4 & 1629 \\
\hline Prod $^{\text {dy }}$ & $86 / 87$ & 1.78 & 1.31 & 1.38 & 0.90 & 0.89 & 0.58 & 5.34 & 0.63 & 25.67 \\
\hline & $96 / 97$ & 2.4 & 1.60 & 1.60 & 1.11 & 1.05 & 0.65 & 9.06 & 0.8 & 35.41 \\
\hline $\begin{array}{l}\text { \% Change Over } \\
10 \text { yrs. }\end{array}$ & $(34.8)$ & $(22.1)$ & $(15.9)$ & $(23.3)$ & $(1.05)$ & $(12.0)$ & $(69.0)$ & $(27.0)$ & $(38.0)$ \\
\hline
\end{tabular}

Source: Statistical information on Nepalese Agriculture, 1996/97.

The table shows that, during ten years the productivity of paddy had not changed drastically, likewise for other cereal crops also it is very negligible. However, a little change can be observed in the case of potato. Although the change in area is also observed, for different crops. For example, the area of sugarcane has increased nearly by double, but its productivity has not increased.

Of all the other factors contributing to the growth of agricultural productivity, irrigation is most probably the leading factor. But irrigation is determined by time factor. Naturally, if there is assured and timely irrigation, productivity accelerated. Low level of soil fertility has also been a causal factor for the low agricultural productivity. Contrast and regular use of the same plot of land without and interval is the main characteristics of Nepalese farming system. In turn it has wduced soil fertility. Hence, a substance system is required to check the loss of soil fertility. Use of local seeds has also delimited the productivity level. However, its usage is little in the Terai region. By Development region, it has been found that about 40 percent farmers in the Eastern and Central region used improve seeds during the year 1991/92, where as the percentage is less that 20 in the rest three Development region. In the same way use of pesticides is also negligible. There is little use in the Terai but even less in the rest of the regions. In addition to the above factors, manuers fertilizer and agricultural market is a complex one. Although the consumption of chemical fertilizer is increasing rapidly but its quantity in use has not increased up to the desired level. Market factor has a close link with agricultural productivity. Nearness and, regular market facilities generally encourage the peasant to cultivate the crops required by the market and consumers. Hence, the market is considered to be decision marker of the peasant.

\section{AGRICULTURAL MARKETING}

Agricultural marketing plays a vital role in agriculture, if otherwise, agriculture product is treated as crux of all other problems. Nepalese peasants do not get fair price for their crops. People in the mountain and many of those in the Hill are devoid in this regard. In the absence of regular and stable market facilities 
products always have to depend upon the local traders who generally exploit the production level. From ecological view-point, Nepal has tremendous scope to accelerate her agricultural growth, but the reality is quite reverse in this respect. Owing to fragile topography, more than $\mathbf{5 0}$ percent of the total agricultural product lacks regular market facilities.

Generally as seen in the case of mountain and many of the hilly regions, the agricultural products have to pass through different stages before they finally reach the consumer level. The various stages of trade in Nepalese agricultural market is illustrated below.

Figure-1: Different Stages of Trade.

\begin{tabular}{|c|c|c|c|c|c|}
\hline Producer & $\begin{array}{c}\text { Local } \\
\text { Traders }\end{array}$ & $\begin{array}{c}\text { Hut } \\
\text { Traders }\end{array}$ & $\begin{array}{c}\text { Whole Sale } \\
\text { Traders }\end{array}$ & Retailer & Consumer \\
\hline & 1st Stage & 2nd Stage & 3rd Stage & 4th Stage & 5th Stage \\
\hline
\end{tabular}

In the first stage of the trade, the local traders collect agricultural products from producer themselves. Here bargaining between the producer and the trader is maximum. Then comes the turn of hut traders in the second stage. Here the local trader sells the product to hut traders. The hut traders collects the products in different huts. The numbers of hut traders is smaller in comparison to local traders. In the third stage of the trade comes the turn of the wholesale trader, who collects the products from the several hut traders. The wholesale traders are generally found in the Terai region. In the fourth stage of trade comes the retailer, who purchases the products from wholesale traders. And finally the products reach the consumer level.

This channel type of trading has exploited the peasant to a great extent. The result is that the producer gets a low value of his products and consumer has to bear a high value. The increase in value of agricultural products as they pass through these different stages, has been illustrated below.

Figure-2: Share of Product Value in Different Stages of Trade.

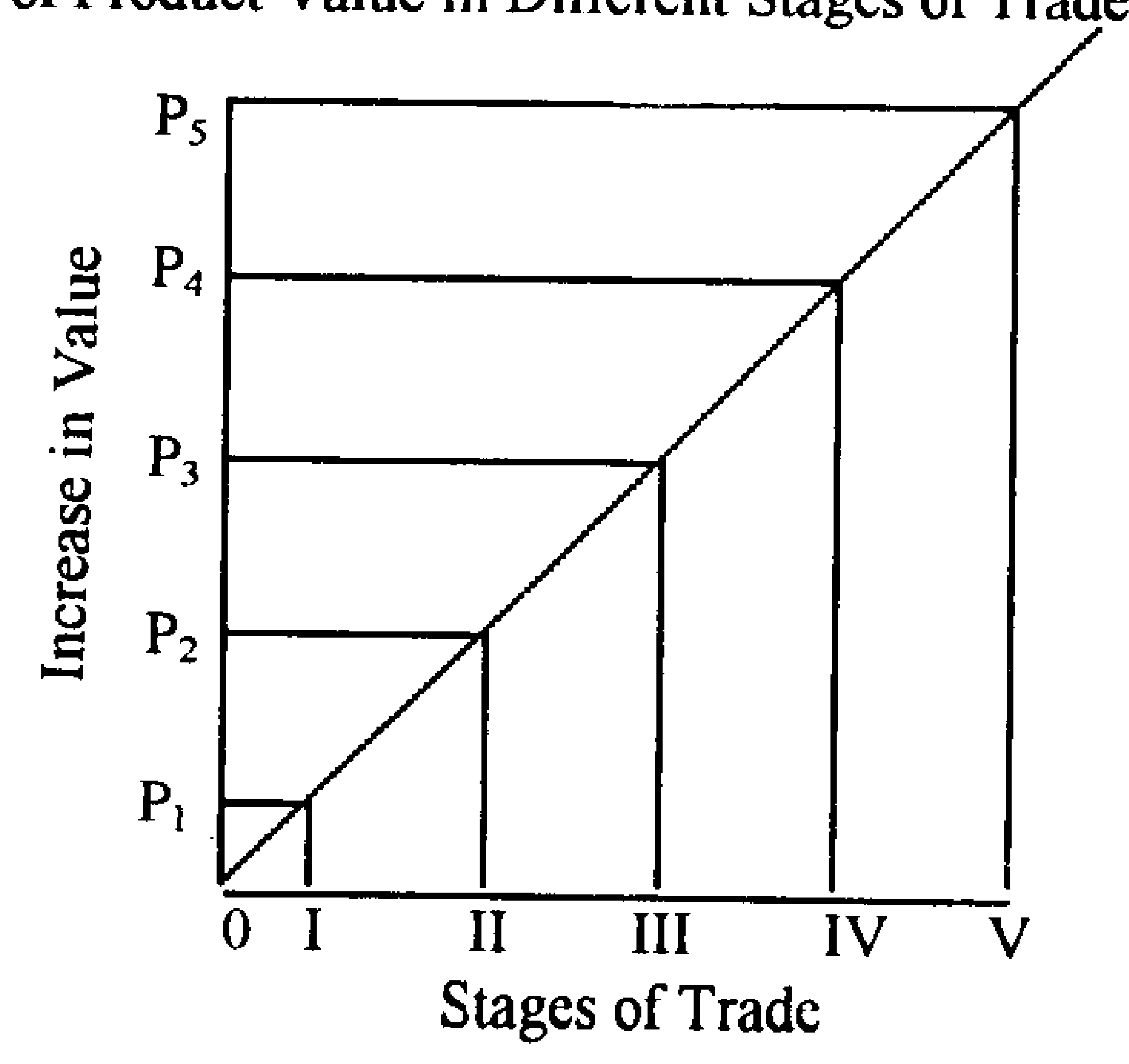


The defective system of agricultural trade in agricultural economy in which Nepalese peasant are engaged is illustrated clearly in fig II. Here in the first stage of

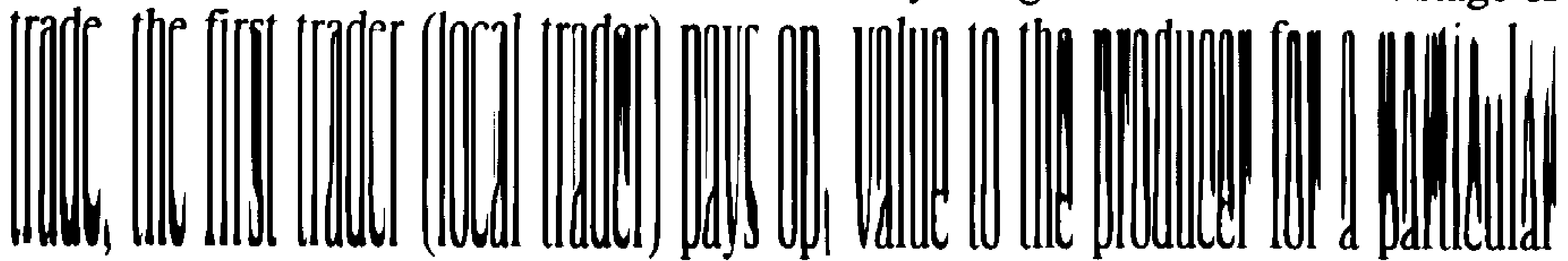

product, this is the least value to the product. Then in the second stage of the trade, the hut trader purchases it by paying op ${ }_{2}$ value. In the same way, in the third stage, the whole sale trader pays op 3 value and finally the last trader, the retailer, pays ${ }_{0} p_{4}$ value and sells it to the consumer at $\mathrm{op}_{5}$ value. In the this way, the value of the product increases from $\mathrm{op}_{1}-o \mathrm{p}_{5}$ levels. This system of agricultural marketing prevailing in the agricultural market of Nepal has not only exploited the Nepalese peasants but also has always left them behind the plough.

\section{LAND FRAGMENTATION}

The pressure of population on land is not equally distributed. Nepal, being an agrarian country has a very high density of population on cultivated rural land, i.e. more than 950 persons per sq. Km. Farm Size have continuously being fragmented. Land fragmentating is considered as one of the various structural problems inhibiting the modernization of agriculture. Such fragmentation of agricultural land in Nepal is attributed to the operation of the lows of inheritance, irregular transfer and leases, growing population and the growth of the spirit of individualism. Those elements have resulted in the subdivision and fragmentation of agricultural holding to the detriment of the efficient agricultural production.

Table-2: Land Fragmentation by Ecological Belt 1991/92.

\begin{tabular}{|l|c|c|}
\hline \multicolumn{1}{|c|}{ Regions } & $\begin{array}{c}\text { Average Fragmentation } \\
\text { Per Farm }\end{array}$ & $\begin{array}{c}\text { No. of fragments per } \\
\text { Hectare }\end{array}$ \\
\hline Mountain & 4.63 & 6.8 \\
\hline Hill & 3.92 & 5.1 \\
\hline Terai & 3.88 & 3.1 \\
\hline Nepal & 3.96 & 4.2 \\
\hline
\end{tabular}

Source: National Sample census of Agriculture 1991/92.

The repeated subdivision and fragmentation of holdings are major problems adversely affecting agriculture. unhampered growth of population has further aggravated the problem as it brings the necessity to break up common lands.

Table-3: Population Density in Cultivated Area (1961-1991).

\begin{tabular}{|c|c|}
\hline Year & Density per Sq. Km. \\
\hline 1961 & 308.29 \\
\hline 1971 & 378.48 \\
\hline 1981 & 468.82 \\
\hline 1991 & 950.00 \\
\hline
\end{tabular}

Source: Statistical pocket book 1982, 1992.

It has found that the high population growth has reduced the size of holdings as well as productivity. The size of holdings is inversely proportionate to 
population, i.e. higher the population, lower will be the size of holdings. From social viewpoint the dimension of the property of the rural landed class may seem to the justified, but economically, it is harmful, for it hampers the use of modern inputs. In comparison to larger size holding smaller size operational holdings are more harmful. During the year 1961/62 the average holding size in Nepal was 1.11 hectares, in $1971 / 72$ it declined to make 0.97 hectares, in $1981 / 82$ it was 1.13 hectares and finally in 1991/92 became only 0.96 hectare.

Table-4: Area and Fragmentation of Holding 1961/62-1991/92.

\begin{tabular}{|l|r|r|r|r|}
\hline \multicolumn{1}{|c|}{ Year } & \multicolumn{1}{|c|}{$1961 / 62$} & \multicolumn{1}{|c|}{$1971 / 72$} & \multicolumn{1}{|c|}{$1981 / 82$} & \multicolumn{1}{|c|}{$1991 / 92$} \\
\hline $\begin{array}{l}\text { No. of holdings with land } \\
\text { (in 000) }\end{array}$ & 158.0 & $1,707.3$ & $2,185.7$ & $2,703.9$ \\
\hline $\begin{array}{l}\text { Average holdings size } \\
\text { (hectares) }\end{array}$ & 1.11 & 0.97 & 1.13 & 0.96 \\
\hline
\end{tabular}

Source: National sample census of Agricultural, 1991/92

The share of lolding size in three ecological belts varies sharply. The size decreases steadily from Terai to Hilly region. The average holding size in the Terai is 1.26 hectares followed by 0.77 hectares in the mountain region. The lowest holding size in the Hills i.e., 0.68 hectares. This small size of holdings in the Hills has attributed to several negative changes i.e. lower agricultural productivity, low use of irrigation facilities and low input etc. These negative changes forces the peasant in the subsistence farming and in turn shows the signs of people stepping on to the level below poverty line.

Table-5: Average Holding Size By Ecological Belt 1991/92.

\begin{tabular}{|l|r|r|r|r|}
\hline \multicolumn{1}{|c|}{ Ecological Belt } & \multicolumn{1}{c|}{ Mountain } & \multicolumn{1}{c|}{ Hill } & \multicolumn{1}{c|}{ Terai } & \multicolumn{1}{c|}{ Nepal } \\
\hline No. of holding (with land 000) & 259.9 & 1351.3 & 1092.8 & 2703.9 \\
\hline Average holding size (ha) & 0.698 & 0.77 & 1.26 & 0.96 \\
\hline
\end{tabular}

Source: National Sample Census of Agriculture, 1991/96.

\section{IRRIGATION SYSTEM}

Nepal's agricultural largely depends on rainfall. Rainfall in Nepal is notoriously uncertain. which increases the element of risk and makes farming rather difficult. Normally rainfall is marked by wide fluctuations in different regions. It also varies from season to reason and year in its quantity, incidence and duration. This unreliable rainfall becomes major impediments for single as well as multiple cropping. The development or irrigation system has long history, yet it has not increased up to the desired level and its development is also very limited. Commercialization of agriculture largely depends on regular and timcly supply of water. But to-topography, to large extent. delimits the development of better irrigation potential throughout the country.

In Nepal, irrigation projects were carried out first, by the department of irrigation in 1952 with technical assistance from India. Later on. this agency was 
transformed into the Department of irrigation Hydrology and Meteorology (DIHM).

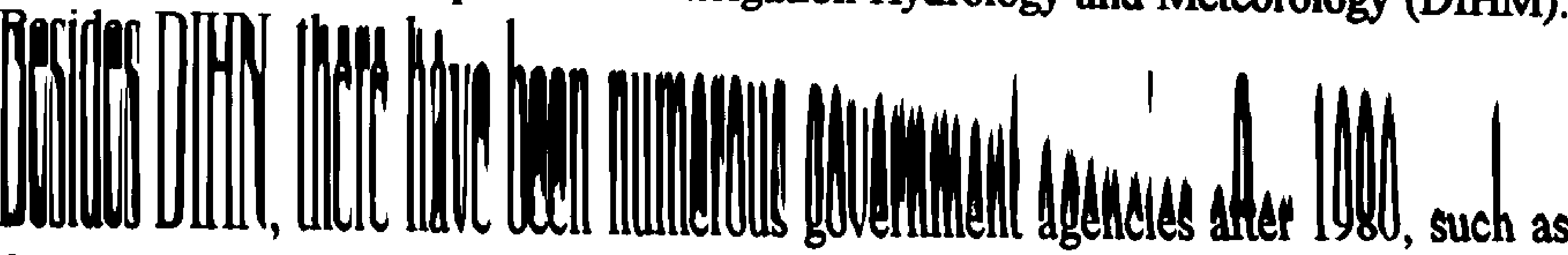

farm Irrigation and Water Utilization Division (FIWUD) of the Department of Agriculture (DOA), The Ministry of Local Development (MOLD) and Agricultural Development Bank (ADB/N). Among non-governmental organizations are: Special Public Work Program (SPWD), Care-Nepal, UMN, SNV and many other integrates Rural Development Projects. Now all these governmental agencies and nongovernmental organizations have started to provide support services and to coordinate with relevant agencies.

Many policies and programme were implemented by different agencies and organizations regarding extension and management of irrigation system in different corners of the country. Even then the system of irrigation has not been developed as expected. Farmer Managed Irrigation System (FMIS) which was formerly known as Agency Managed Irrigation System (AMIS), has to some extent clarified the confusions on the mechanism of management. However, for operation and management, the users have full control over it, which may some times creates controversy among the users.

Substantial increment is often found in the objectives of different five year plans in order to meet the requirement of the farmers by providing regular and timely irrigation facilities. Every plan allocates maximum developmental budget to agriculture sector. The share of total budget for agriculture sector and forestry in the fifth, sixth, seventh and eighth five year plans was $26.5,30.4,30.6$ and 25.8 percent respectively. Out of the every total agricultural development budget, irrigation subsector shares 10.9 percent, 14.1 percent, 17.4 percent and 10.54 percent in these four five year plans respectively, as is evidence from the table below.

Table-6: Percent Share of Total Agricultural Forestry Sector and Irrigation Subsector in the Total Developmental Budget during Fifth to Eight Five Year Plans.

\begin{tabular}{|l|c|c|}
\hline \multirow{2}{*}{ Five year plan } & $\begin{array}{c}\text { Percent Share of Total } \\
\text { Development Budget }\end{array}$ & $\begin{array}{c}\text { Percent Share of total } \\
\text { Agricultural Budget }\end{array}$ \\
\cline { 2 - 3 } & Agriculture Sector & Irrigation Sub-sector \\
\hline Fifth Plan & 36.5 & 10.9 \\
\hline Sixth Plan & 30.4 & 14.1 \\
\hline Seventh Plan & 30.6 & 11.4 \\
\hline Eighth Plan & 25.8 & 10.5 \\
\hline
\end{tabular}

Source: National Planning Commission 6th, 7th and 8th Five Year Plan.

The out going eighth five year plan had paid due attention to short as well as long term irrigation program in the feasible areas of the Mountain and the Terai regions to boost food production. The seventh five year plan had also made policies in the food deficit hilly districts by providing irrigation canals already in existence along with whatever else is available in the form of rivers and rivulets, ponds and tanks etc. But the question arises in the minds of an ordinary person, why in large 
part of the country, farmers have to depend on monsoon. Peasants are not getting sufficient food for subsistence. Policies and programs made in the previous plan are abandoned without examining and correcting the defectives is the reality.

Water potential in Nepal is vast. This can be tapped and usefully used for irrigation, domestic consumption and industrial purpose. But on an average 1.1 million hectares of land has been benefited from the irrigation facilities. And out of this, only 38 percent potential is for the year-round irrigation, and the rest has to wait for monsoon. The table below show the expansion of irrigated land during 1985-1994.

Table-7: Irrigated Area by Development Region 1985-1994.

(Area in Hectare)

\begin{tabular}{|l|r|r|r|r|r|r|r|r|r|r|}
\hline $\begin{array}{l}\text { Develop- } \\
\text { ment } \\
\text { Region }\end{array}$ & \multicolumn{90}{|c|}{ Years } \\
\hline & 1985 & 1986 & 1987 & 1988 & 1989 & 1990 & 1991 & 1992 & 1993 & 1994 \\
\hline EDR & 28930 & 4000 & 12700 & 2775 & 7266 & 3634 & 3163 & 4551 & 4814 & 9259 \\
\hline CDR & 3330 & 1375 & 120 & 1330 & 6828 & 2822 & 3560 & 3748 & 17840 & 9032 \\
\hline WDR & 2902 & 1010 & 640 & 1715 & 5161 & 5878 & 5406 & 6141 & 5424 & 6857 \\
\hline MWDR & 1100 & 250 & - & - & 6267 & 967 & 669 & 1153 & 1687 & 2471 \\
\hline FWDR & 4545 & 2900 & 1950 & 800 & 5545 & 2655 & 1443 & 108 & 368 & 5200 \\
\hline Total & 40477 & 10135 & 15680 & 9670 & 35015 & 24492 & 20810 & 33833 & 59636 & 57806 \\
\hline
\end{tabular}

Source: Statistical Vear Book, 1995.

Although, the area of irrigated land has been increasing year after year, but the level of productivity has not increased to desired level. Problems regarding the irrigation had been identified by planners, administrators and politicians. Heavy investment is invested in workshop, seminars and so on. But the situation is the same i.e. farmers have to wait the vagarious of monsoon every year even when there is irrigation facilities.

Realizing the performance of the previous plans and sighting the for thecoming problems, APP has proposed a 20 years master plan project to accelerate the agricultural growth rate. It pays due attention to irrigation system. In Terai, main emphasis is given in ground water scheme and in the hilly and mountain region it gives heavy emphasis in surface water scheme. Another merit of this project is that the management of the irrigation project in the initial phase is not in the hands of the farmers. Later on, the schemes will be farmer management.

\section{MANURES AND FERTILIZERS}

Fertilizer is the key input in increasing the agricultural productivity. Other things remaining the same every tons of nutrient increases the yield by about 10 tons of food grains. But it should be kept in mind that manure's and fertilizers can do nothing if they are not supplied regularly and adequately in Nepal about 55 percent of the total arable land lies in the Terai region and the rest 45 percent lies in the mountain and the hilly region. The mountains and many of the hill regions lack transport facilities. Thus, owing to the fragile topography, the most remote areas are devoid of using fertilizers when it is needed. 
Although the consumption of chemical fertilizer is accelerating, it is negligible in comparison to other SAARC countries. According to World

Development Report, the consumption of chemical fertilizer was 97 hundred grams per hectare in 1979/80 and it increased to 391 hundred grams per hectare in 1993.

Table-8: Fertilizer Consumption in Nepal and Neighbouring Countries 1979/80 and 1992/93.

\begin{tabular}{|l|c|c|}
\hline \multirow{2}{*}{ Country } & \multicolumn{2}{|c|}{ Fertilizer Used (Hundred gm/ha of arable land) } \\
\cline { 2 - 3 } & \multicolumn{2}{|c|}{ Year } \\
\cline { 2 - 3 } & $1979 / 80$ & $1992 / 93$ \\
\hline Bangladesh & 455 & 1032 \\
\hline Sri Lanka & 882 & 964 \\
\hline India & 329 & 720 \\
\hline Pakistan & 532 & 1015 \\
\hline Nepal & 97 & 391 \\
\hline
\end{tabular}

Source: World Development Report, 1995.

Soil reserves have to be supplemented by fertilizer dressing. Maximum yields can be obtained if fertilizer dressing of the three major plant-foods, nitrogen, Phosphate, and potash is supplied in properly balanced amounts to suit the crop and to make up the deficiency of the soil.

The overall nitrogenous fertilizer consumption in Nepal was 66687 metric tons in 1994/95, the consumption was 25140 metric tons and that of potash was 1680 metric tons. The total fertilizer consumption during the same year was 93507 metric tons.

Fertilizer consumption in the three ecological belts is not equal. More than 66 percent growers used chemical fertilizer for rice crops in the Terai whereas the percentage is higher is the case of maize crops in the mountain and the hill regions. On the other hand the percentage of maize growers in the Terai is less than that in the mountains and the hills. This is due to the fact that the farmers of these regions use maize and potato for the substitution of paddy as their food.

Table-9: Percentage of Chemical Fertilizer User by Ecological belt 1991/92.

\begin{tabular}{|l|c|c|c|c|}
\hline Ecological belt & Rice Grower & $\begin{array}{c}\text { Wheat } \\
\text { Grower }\end{array}$ & $\begin{array}{c}\text { Maize } \\
\text { Grower }\end{array}$ & Potato Grower \\
\hline Mountain & 26.3 & 17.2 & 25.2 & 8.9 \\
\hline Hill & 35.0 & 36.7 & 23.8 & 26.0 \\
\hline Terai & 66.2 & 78.7 & 16.9 & 41.5 \\
\hline
\end{tabular}

Source: National Sample Census of Agriculture, 1991/92.

The economic condition of the small farmers in general, plays an important role in supplying the fertilizer on their farm. Another factor is that the most of the fertilizer subsidy goes in the hands of rich man. Nepal lacks regular market except hut bazaars in the rural areas. Absence of regular market discourage the peasant to 
cultivate the land by applying high input technologies. Besides, the technical knowledge of fertilizer use in the three ecological belt is not same. It is some what known by the Terai peasant in comparison to mountain and hill peasants.

\section{CONCLUSION}

Nepal is far behind in agricultural growth as compared to other developing countries of the world. His Majesty's Government of Nepal is making as much as possible efforts to achieve the target level. But even than it is not fruitful as what is imagined. Agriculture, is still done in a traditional way. Agriculture productivity is far behind. Population is increasing at a faster rate, but the rate of production is very slow. Peasants are not getting reliable prices for their products. Sources of irrigation are many but they are not utilized properly whatever they are developed, they are not for year round and have to wait for monsoon. In the same way manure's an fertilizers are not used in a balanced quantity hence which hampers for better the productivity.

\section{WORKS CITED}

APROSC, JMA (1995), Nepal: Agricultural Perspective Plan. Final Report. Main Document, Agricultural Projects Service Center, Kathmandu and John Mellor Associates, INC, Washington DC.

MOA (1996/97), Statistical Information on Nepalese Agriculture. Ministry of Agriculture HMG/Nepal.

NPC (1991/92), National Sample Census of Agriculture. National Planning Commission Secretariat, HMG/Nepal.

NPC (1995/96), Statistical Year Book. National Planning Commission Secretariat, $\mathrm{HMG} / \mathrm{Nepal}$.

NPC (1982), Statistical Pokcet Book. National Planning Commission Secretariat. HMG/Nepal.

NPC (1992), Statistical Pocket Book. National Planning Commission Secretariat. HMG/Nepal.

NPC (1980), Sixth Five Year Plan 1980/81-1984/85. National Planning Commission, HMG/Nepal.

NPC (1985), Seventh Five Year Plan 1985/86-1989-90. National Planning Commission, HMG/Nepal.

NPC (1992), Eight Five Year Plan 1992/93-1996/97. National Planning Commission, HMG/Ncpal.

Shrestha, S.M. (1985), "Stratcgics for Small Farmers Marketing lmprovement in Nepal." The Economic Journal of Nepal. Vol. 18. No. 1. Kirtipur. T.U.. Central Department of Economics.

World Bank (1995). Washington DC .World Devclopment Report-1995. 